\title{
IS DYNAMIC TWO-DIMENSIONAL ANAL ULTRASONOGRAPHY USEFUL IN THE ASSESSMENT OF ANISMUS? A COMPARISON WITH MANOMETRY
}

\author{
Sthela Maria MURAD-REGADAS ${ }^{1}$, Francisco Sérgio P. REGADAS ${ }^{1}$, \\ Rosilma Gorete Lima BARRETO², Lusmar Veras RODRIGUES', \\ Graziela Olivia da Silva FERNANDES ${ }^{2}$ and Doryane Maria dos Reis LIMA ${ }^{2}$
}

\begin{abstract}
Context - Anismus is a prevalent functional cause of outlet delay. It is characterized by symptoms of obstructed defecation associated with paradoxical contraction of the pelvic floor muscles. Objective - To evaluate the ability of two dimensional anal ultrasonography to identify anismus patients with paradoxical contraction or normal relaxation, comparing findings with manometric measurements. Methods - Forty-nine women presenting with outlet delay and a mean validated Wexner constipation score of 13.5 were included in a prospective study. Following screening with anal manometry, the patients were assigned to one of two groups: G-I - with normal relaxation and G-II - patients with anismus. Dynamic anorectal ultrasonography was used to quantifier the movement of the puborectalis muscle and to measure changes in the angle between two converging lines drawn from the 3 o'clock and the 9 o'clock positions of the endoprobe circumference to the internal border of the puborectalis muscle. The angle decreases during straining in patients with normal relaxation, but increases in patients with anismus. The agreement between the two techniques was verified with the Kappa index. Results - In manometry, during straining the anal canal pressure decreased by $41.3 \%$ in G-I and increased by $168.6 \%$ in G-II, indicating a diagnosis of anismus for the second group. In US, during straining, the angle produced by the movement of the puborectalis muscle decreased from $63 \pm 1.31$ to $58 \pm 1.509$ degrees $(P=0.0135)$ in 23 of the 30 patients in G-I, indicating normal relaxation, and increased from $66 \pm 0.972$ to $72 \pm 0.897$ degrees $(P=0.0001)$ in 16 of the 19 patients in G-II, indicating anismus. The index of agreement between manometry and two dimensional anal ultrasonography was moderate: $77 \%$ (23/30) for G-I and 84\% (16/19) for G-II. Conclusion - Two-dimensional dynamic anal ultrasonography showed similar results previously suggested by anal manometry at identifying patients with normal relaxation or paradoxical contraction.

HEADINGS - Endosonography. Anus diseases, ultrasonography. Constipation, ultrasonography. Manometry.
\end{abstract}

\section{INTRODUCTION}

Intestinal constipation involves factors related to evacuation frequency and, due to anatomical and functional changes in the pelvic floor, can lead to changes in colonic transit time and obstructed evacuation ${ }^{(5,}$ 17). Clinically, obstructed evacuation is suggested by forced straining during defecation, sensation of incomplete evacuation and use of digital maneuver, with or without normal defecation frequency. Once identified and quantified, anatomical and functional changes can be correlated with clinical symptoms and proctological findings ${ }^{(6)}$. Defecography, manometry, electromyography and, more recently, dynamic magnetic resonance scanning and dynamic anorectal ultrasonography, have all been used to diagnose

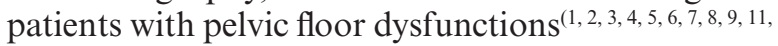

$12,13,14,15,16,17,18,19,20,21,22,23,24,26,27,28,29,30)$. Advances in ultrasound technology includes the development of the three-dimensional (3D) anorectal transducer and allows to clearly visualize the anatomic configuration of the anal canal in multiplane images ${ }^{(27)}$ but the twodimensional (2D) ultrasound can be useful in the diagnosis of anorectal disease ${ }^{(7,10,24)}$.

Anismus is a prevalent functional cause of outlet delay. It is characterized by symptoms of obstructed defecation associated with paradoxical contraction of the pelvic floor muscles ${ }^{(25)}$. Dynamic endosonography has become an important diagnostic tool in anismus patients as it allows to visualize the anal sphincters

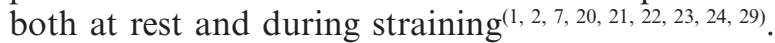
Recently, Murad-Regadas et al. ${ }^{(23)}$ described a novel technique for the assessment of anismus using dynamic two-dimensional anal ultrasonography (2D-DAUS)

${ }^{1}$ Departamento de Cirurgia, Faculdade de Medicina da Universidade Federal do Ceará, Fortaleza, CE; ${ }^{2}$ Centro de Coloproctologia e Gastroenterologia do Ceará, Hospital São Carlos, Fortaleza, CE, Brazil.

Correspondence: Dr. Sthela M. Murad Regadas - Av. Edílson Brasil Soares, 1892 - Edson Queiroz - 60834-220-Fortaleza, CE, Brazil. Email: smregadas@hospitalsaocarlos.com.br 
with satisfactory results when compared to dynamic threedimensional anal ultrasonography (3D-DAUS). The purpose of this prospective study was to evaluate the ability of 2D-DAUS to identify patients with paradoxical contraction (anismus) or normal relaxation, comparing with manometric findings.

\section{METHODS}

Forty-nine women presenting with outlet delay (excessive straining at evacuation, vaginal maneuver and sensation of incomplete evacuation) and a mean validated Wexner constipation score of 13.5 (range: 8.0-20.0) were included in a prospective study from August 2008 to June 2009. Following screening with anal manometry, the patients were assigned to one of two groups: G-I - 30 patients with normal relaxation (average age: 48.63 years; range: 24-69), and G-II -19 patients with paradoxical pelvic floor muscle contraction (anismus) (average age: 51.20 years; range: 27-78). Fifteen women from G-I and nine from G-II had undergone at least one vaginal delivery. All patients were subsequently submitted to 2D-DAUS.

The study was previously approved by the local hospital ethics committee and all patients provided informed consent for both study procedures.

\section{Anorectal manometry}

Anorectal manometry was performed with a 4-channel Viotti $^{\circledR}$ device (Gastrosystem DS 8800) with continuous water perfusion, calculating the length of the anal canal, anal canal pressure at rest, maximum anal squeezing, adequate capacity to sustain the squeeze pressure, pressure during straining and rectoanal reflex. Normal anal relaxation is demonstrated when the anal canal pressure decreased any pressure during straining. Otherwise, patients with increased anal canal pressure during straining were diagnosed with anismus. Catheter was located at the highest pressure zone and this measurement was repeated three times. All evaluations were performed by the same examiner. It was excluded those that the pressures not changed during straining (no relaxation).

\section{Dynamic anal ultrasonography}

Dynamic anorectal ultrasonography was performed with a B-K Medical ${ }^{\circledR}$ device using a 360 -degree rotating endoprobe. The examiner was blinded to the results of the manometry.

Following rectal enema, patients were examined in the left lateral position. The endoprobe was inserted into the lower rectum as far as required to visualize the puborectalis (PR) muscle in the upper anal canal. With the endoprobe in a fixed position, the patient was asked to strain maximally. This procedure was repeated 3 times. The movement of the PR muscle was quantified by measuring changes in the angle between two converging lines drawn from the 3 o'clock and the $9 \mathrm{o}$ 'clock positions of the endoprobe circumference to the 6 o'clock position on the internal border of the PR muscle. The angle decreases at least $1^{\circ}$ during straining in patients with normal relaxation, but increases at least $1^{\circ}$ in patients with anismus ${ }^{(23)}$. The same patient should be compared at rest with straining. It was not possible determine the range of the angle that will be identified the patient at rest or straining due the difference in anatomical configuration. In addition, the anatomical integrity of the sphincter muscles was evaluated.

\section{Statistical analysis}

Findings were analyzed with Student's $t$ test. The level of statistical significance was set at $P<0.05$. The agreement between the two techniques was verified with the Kappa index.

\section{RESULTS}

\section{Anorectal manometry}

The mean resting anal canal pressures in G-I and G-II were $62.7 \pm 3.382 \mathrm{~mm} \mathrm{Hg}$ (range: $34.0-93.5$ ) and $51.8 \pm 3.005 \mathrm{~mm}$ $\mathrm{Hg}$ (range: $36.1-82.3$ ), respectively $(P>0.05)$. During straining the anal canal pressure decreased from $66.53 \pm 3.712$ to 35.18 $\pm 3.185 \mathrm{~mm} \mathrm{Hg}(41.3 \%)$, in G-I and increased from $52.07 \pm$ 2.996 to $106.9 \pm 8.357 \mathrm{~mm} \mathrm{Hg}(168.6 \%)$ in G-II, indicating a diagnosis of anismus for the second group (Figures 1,2).

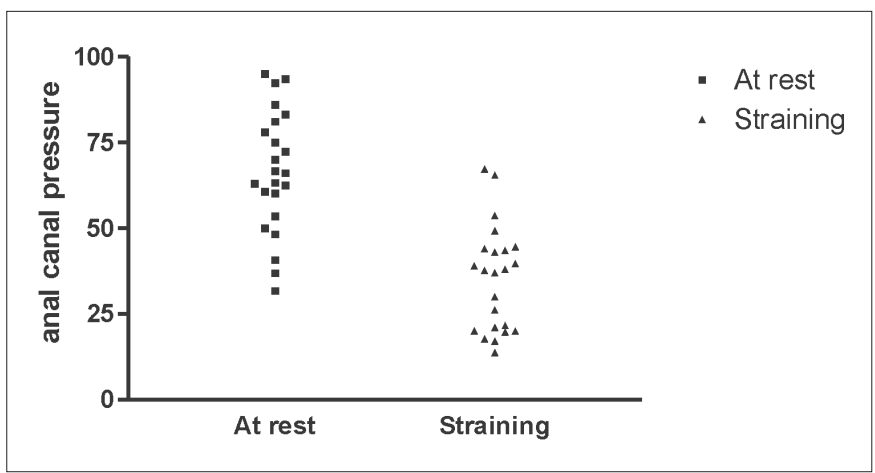

FIGURE 1. Anorectal manometry - normal relaxation (G-I) patient. The anal canal pressures decreased compared at rest with straining

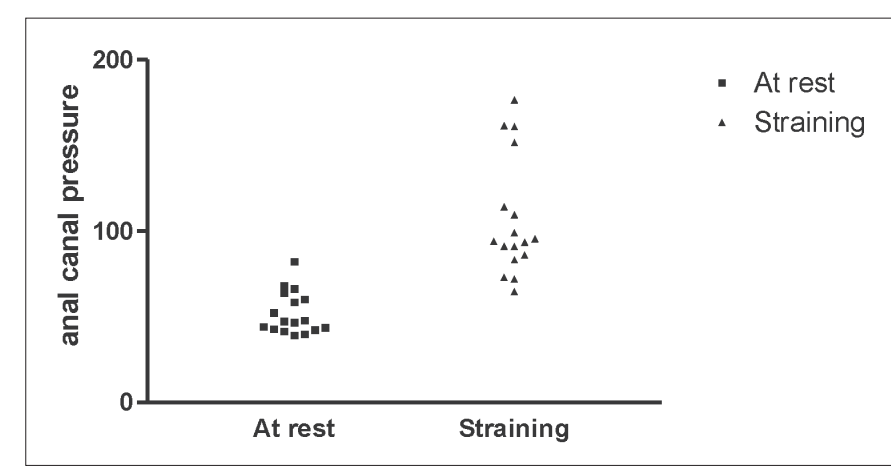

FIGURE 2. Anorectal manometry - anismus (G-II) patient. The anal canal pressures increased compared at rest with straining

\section{D-DAUS}

Upon straining, the angle produced by the movement of the PR muscle decreased from $63 \pm 1.31$ to $58 \pm 1.42$ degrees $(P=0.0135)$ in 23 of the 30 patients in G-I, indicating normal 
Murad-Regadas SM, Regadas FSP, Barreto RGL, Rodrigues LV, Fernandes GOS, Lima DMR. Is dynamic two-dimensional anal ultrasonography useful in the assessment of anismus? A comparison with manometry

relaxation (Figures 3,4 ), and increased from $66 \pm 0.972$ to $72 \pm 0.897$ degrees $(P=0.0001)$ in 16 of the 19 patients in G-II, indicating anismus (Figures 5,6).

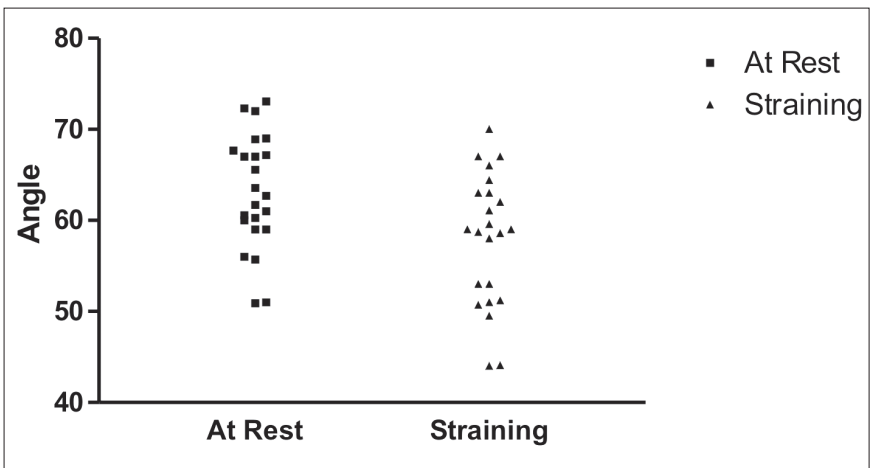

FIGURE 3. 2D-DAUS angle - normal relaxation (G-I) patient. Puborectalis angle decreased compared at rest with straining

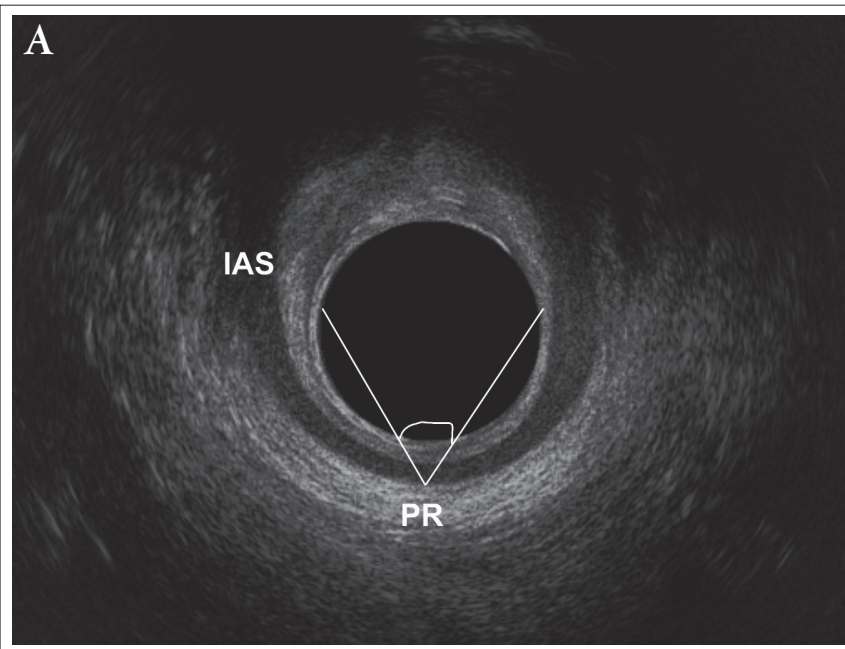

B

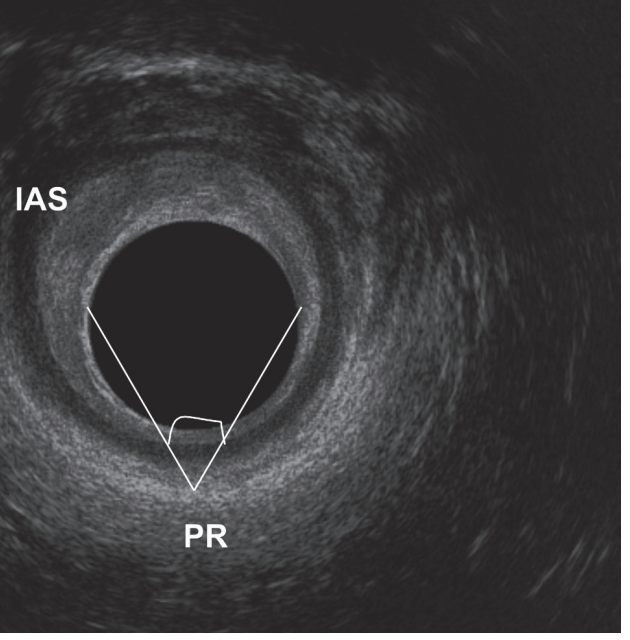

FIGURE 4. 2D-DAUS - normal relaxation (G-I) patient.

Puborectalis angle decreased. (a) at rest, (b) straining, PR - puborectalis muscle/IAS - internal anal sphincter

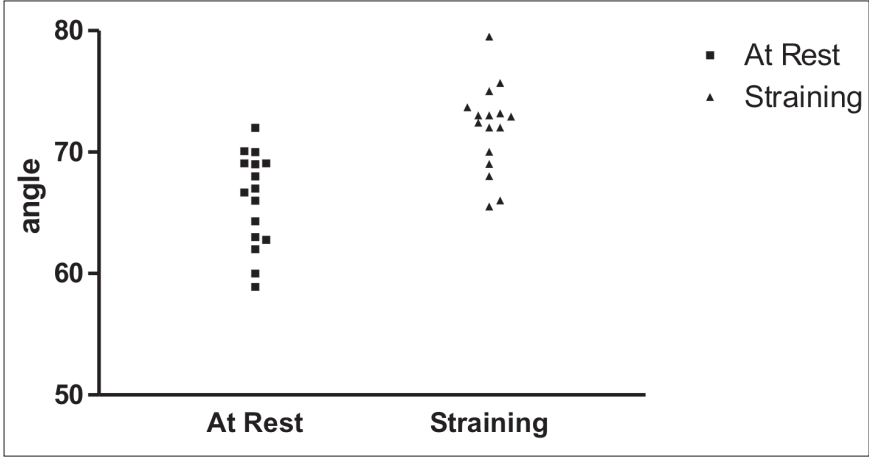

FIGURE 5. 2D-DAUS angle - anismus (group II) patient. Puborectalis angle increased compared at rest with straining

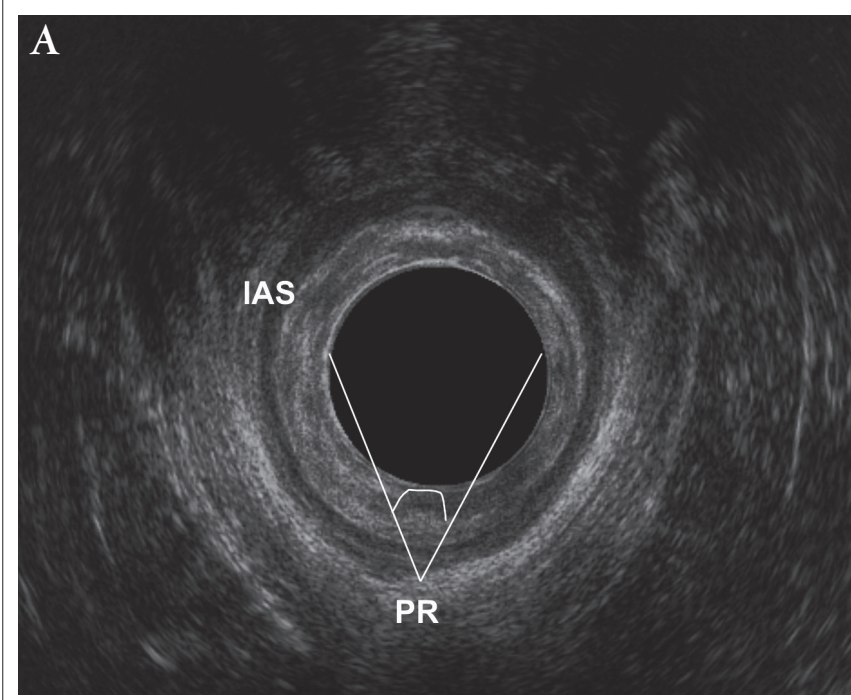

B

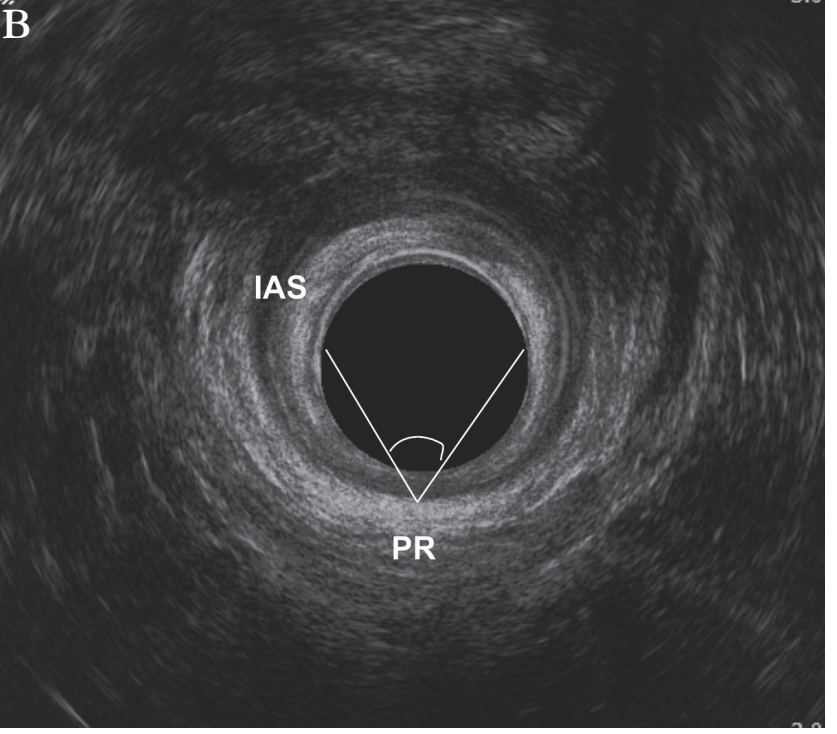

FIGURE 6. 2D DAUS - anismus (group II) patient.

Puborectalis angle increased.(a) at rest, (b) straining, PR - puborectalis muscle/IAS - internal anal sphincter 
The index of agreement between manometry and ultrasonography was moderate: $77 \%$ (23/30) for G-I and $84 \%$ (16/19) for G-II (Kappa: 0.586; CI: 95\%; range: 0.51-1.0). No sphincter injury was observed.

\section{DISCUSSION}

Anorectal manometry is highly accurate in the identification of anismus. Moreover, in several studies on anismus, manometry and defecography have yielded similar results ${ }^{(4,8,12,26)}$.

In the present study, anorectal manometry was used to screen patients with paradoxical sphincter muscle contraction (G-II) and patients with normal muscle relaxation (G-I). Patients with no relaxation during straining were excluded. No preparation or digital examination was performed prior to anorectal manometry.

Anorectal dysfunctions have been successfully investigated using dynamic ultrasonography techniques and a variety of transducers. In an assessment of patients with anismus, Van Outryve et al. ${ }^{(29)}$ used linear transrectal sonography to measure muscle length and thickness at rest and during straining and found statistically significant differences. Brusciano et al. ${ }^{(7)}$ used 2-D endosonography to identify anismus in patients with obstructed defecation and concluded that during straining differences of less than $0.5 \mathrm{~cm}$ between the internal border of the PR and the transducer are suggestive of anismus. Murad-Regadas et al. ${ }^{(22)}$ developed the 3D-DAUS technique to evaluate the movement of the PR muscle during straining and found the technique to be in almost perfect agreement with defecography. 3D-DAUS may also conveniently be used to identify anorectal dysfunctions such as rectocele, intussusception and enterocele ${ }^{(20,22)}$.
Recently, Murad-Regadas et al. ${ }^{(23)}$ described a novel technique for the assessment of anismus using 2D-DAUS with satisfactory results and substantial agreement with 3D-DAUS findings. In the present study, 2D-DAUS agreed moderately with anorectal manometry, identifying 23 of 30 patients with normal relaxation and 16 of 19 patients with anismus. Straining was repeated at least 3 times during both examinations. The diagnosis of animus requires an increase of over one degree in the angle between the endoprobe circumference and the internal border of the PR during straining. In spite of being limited to a specific point of the anal circumference, at the level of the PR, the 2D-DAUS technique allows to clearly visualize the movement of the pelvic floor muscles. In patients with normal relaxation, the angle decreases (downward movement) during straining, as opposed to patients with paradoxical contraction of the pelvic floor muscles. In spite of the positive results of the study, the 2D-DAUS technique requires further testing and comparison with other diagnostic tools used to assess anismus. 2D-DAUS is minimally invasive and well tolerated and may be used to evaluate the anatomic integrity of the anal sphincters, even in patients without fecal incontinence to identified occult lesions. This methods can be one option to evaluated this dysfunctions when the 3D-DAUS is not available.

\section{CONCLUSION}

Two-dimensional dynamic anal showed similar results previously suggested by anal manometry at identifying patients with normal relaxation or paradoxical contraction.

Murad-Regadas SM, Regadas FSP, Barreto RGL, Rodrigues LV, Fernandes GOS, Lima DMR. A ultrassonografia anal bi-dimensional pode ser utilizada na avaliacão do anismus? Estudo comparativo com a manometria. Arq Gastroenterol. 2010;47(4):368-72.

RESUMO - Contexto - O anismus é uma causa funcional frequente de evacuação obstruída. Caracteriza-se por sintomas de evacuação obstruída associada à presença de contração paradoxal dos músculos do assoalho pélvico. Objetivo - Avaliar o papel do ultrassom anorretal bidimensional dinâmico em identificar pacientes com contração paradoxal (anismus) ou relaxamento normal, comparando os resultado com medidas manométricas. Métodos - Quarenta e nove mulheres com evacuação obstruída e com média de escore de constipação de 13.5 foram incluídas neste estudo prospectivo. Os pacientes foram divididos em dois grupos, de acordo com os achados da manometria: G-I - presença de relaxamento normal e G-II - paciente com contração paradoxal. Ultrassom anorretal bidimensional dinâmico avaliou e quantificou o movimento do músculo puborretal, utilizando o ângulo formado por duas linhas posicionada às $3 \mathrm{e} 9 \mathrm{~h}$ na circunferência do transdutor convergindo na posição de $6 \mathrm{~h}$, na borda interna do músculo puborretal. O ângulo diminui durante a evacuação em pacientes com relaxamento normal, mas aumenta em pacientes com anismus. A concordância entre as duas técnicas foi verificada utilizando-se o índice de Kappa. Resultados - Na manometria, durante o esforço evacuatório, a pressão do canal anal reduziu $41.3 \%$ no G-I e aumentou $168.6 \%$ no G-II, indicando o diagnóstico de anismus no segundo grupo. No ultrassom anorretal bidimensional dinâmico, durante o esforço evacuatório, o ângulo do músculo puborretal diminuiu de $63 \pm 1.31$ para $58 \pm 1.509$ graus $(P=0.0135)$ em 23 dos 30 pacientes no G-I, indicando relaxamento normal, e aumentou de $66 \pm 0.972$ para $72 \pm 0.897$ graus $(P=0.0001)$ em 16 dos 19 pacientes no G-II, indicando anismus. O índice de concordância entre a manometria e o ultrassom anorretal bidimensional dinâmico foi moderado: $77 \%$ (23/30) para o G-I e 84\% (16/19) para o G-II. Conclusão - Ultrassonografia anal bidimensional dinâmica demonstrou resultados similares aos previamente sugeridos pela manometria anorretal na identificação de pacientes com relaxamento normal ou contração paradoxal.

DESCRITORES - Endossonografia. Doenças do ânus, ultrassonografia. Constipação intestinal, ultrassonografia. Manometria. 


\section{REFERENCES}

1. Barthet M, Portier F, Heyries L, Orsoni P, Bouvier M, Houtin D, Barriere N, Mambrini P, Salducci J, Grimaud JC. Dynamic anal endosonography may callenge defecography for assessing dynamic anorectal disorders: results of a prospective pilot study. Endoscopy. 2000;32:300-5.

2. Beer-Gabel M, Teshler M, Schechtman E, Zbar AP. Dynamic transperinea ultrasound vs. defecography in patients with evacuatory difficulty: a pilot study. Int J Colorectal Dis. 2004;19:60-7.

3. Bolog N, Weishaupt D. Dynamic MR imaging of outlet obstruction. Rom J Gastroenterol. 2005;14:293-302.

4. Borowitz SM, Sutphen J, Ling W, Cox DJ. Lack of correlation of anorectal manometry with symptoms of chronic childhood constipation and encopresis Dis Colon Rectum. 1996;39:400-5.

5. Bouchoucha M, Devroede G, Arhan P, Strom B, Weber J, Cugnenc PH, Denis $\mathrm{P}$, Barbier JP. What is the meaning of colorectal transit time measuremant? Dis Colon Rectum. 1992;35:773-82.

6. Bouchoucha M, Devroede G, Arsac M. Anismus: a marker of multi-site functional disorders? Int J Colorectal Dis. 2004;19:374-9.

7. Brusciano L, Limongelli P, Pescatori M, Napolitano V, Gagliard G, Maffettone V, Rossetti G, del Genio G, Russo G, Pizza F, Del Genio A. Ultrasonographic patterns in patients with obstructed defaecation. Int J Colorectal Dis. 2007;22:96977.

8. Duthie GS, Bartolo DC. Anismus: the cause of constipation? Results of investigation and treatment. World J Surg. 1992;16:831-5.

9. Dvorkin LS, Hetzer F, Scott SM, Williams NS, Gedroyc W, Lunniss PJ. Openmagnet MR defaecography compared with evacuation proctography in the diagnosis and management of patients with rectal intussusception. Colorectal Dis. 2004;6:45-53.

10. Esclapez-Valero JP, García-Botello S. Current utility of endoanal ultrasound in the diagnosis of benign proctological disease. Cir Esp. 2005;78:8-14.

11. Fielding JR. Practical MR Imaging of Female Pelvic Floor Weakness. Radiographics 2002;22:295-304

12. Ger GC, Wexner SD, Jorge JM, Salanga VD. Anorectal manometry in the diagnosis of paradoxical puborectalis syndrome. Dis Colon Rectum. 1993;36:816-25.

13. Gufler H, Laubenberger J, DeGregorio G, Dohnicht S, Langer M. Pelvic floor descent: dynamic MR imaging using a half-Fourier RARE sequence. J Magn Reson Imaging. 1999;9:378-83.

14. Jorge JM, Wexner SD, Ger GC, Salanga VD, Nogueras JJ, Jagelman DG Cinedefecography and electromyography in the diagnosis of nonrelaxing puborectalis syndrome. Dis Colon Rectum. 1993;36:668-76.

15. Kelvin FM, Maglinte DD, Hale DS, Benson JT. Female pelvic organ prolapse: a comparison of triphasic dynamic MR imaging and triphasic fluoroscopic cystocolopoproctography. AJR Am J Roentgenol. 2000;174:81-8.
16. Lienemann A, Anthuber C, Baron A, Kohz P, Reiser M. Dynamic MR colpocystorectography assessing pelvic-floor descent. Eur Radiol. 1997;7:1309-17.

17. Longstreth GF, Thompson WG, Chey WD, Houghton LA, Mearin F, Spiller RC. Functional bowel disorders. Gastroenterology. 2006;130:1480-91.

18. Lubowski D, King DW, Finlay IG. Electromyography of the pubococcygeus muscles in patients with obstructed defaecation. Int J Colorectal Dis. 1992;7:184-7.

19. Mellgreen A, Bremmer S, Johansson C, Dolk A, Udén R, Ahlbäck SO, Holmström B. Defecography: results of investigations in 2,816 patients. Dis Colon Rectum. 1994;37:1133-41.

20. Murad-Regadas SM, Regadas FSP, Rodrigues LV, Escalante RD, Silva FRS, Lima DMR, Soares FA, Barreto RGL, Regadas Filho FSP. Ecodefecografia tridimensional dinâmica. Nova técnica para avaliação da síndrome da defecação obstruída (SDO). Rev bras Coloproctol. 2006;26:168-77.

21. Murad-Regadas SM, Regadas FS, Rodrígues LV, Souza MH, Lima DM, Silva FR, Filho FS. A novel procedure to assess anismus using three-dimensional dynamic anal ultrasonography. Colorectal Dis. 2007;9:159-65.

22. Murad-Regadas SM, Regadas FS, Rodrígues LV, Silva FR, Soares FA, Escalante RD. A novel three-dimensional dynamic anorectal ultrasonography technique (echodefecography) to assess obstructed defecation, a comparison with defecography. Surg Endosc. 2008;22:974-9.

23. Murad-Regadas SM, Regadas FS, Barreto RG, Rodrígues LV, de Souza MH. A novel two-dimensional dynamic anal ultrasonography technique to assess anismus comparing with three-dimensional echodefecography. Colorectal Dis. 2009;11:872-7.

24. Piloni V, Spazzafumo L. Evacuation sonography. Tech Coloproctol. 2005;9:119-26.

25. Preston DM, Lennard-Jones JE. Anismus in chronic constipation. Dig Dis Sci. 1985;30:413-8

26. Rao SS, Tuteja AK, Vellema T, Kempf J, Stessman M. Dyssynergic defecation: demographics, symptoms, stool patterns and quality of life. J Clin Gastroenterol. 2004;38:680-5

27. Regadas SM, Regadas FS, Silva FR, Lima DM, Regadas-Filho FS. Importância do ultra-som tridimensional na avaliação anorretal. Arq Gastroenterol. $2005 ; 42: 226-32$

28. Sutphen J, Borowitz S, Ling W, Cox DJ, Kovatchev B. Anorectal manometric examination in encopretic-constipated children. Dis Colon Rectum. 1997;40:1051-

29. Van Outryve SM, Van Outryve MJ, De Winter BY, Pelckmans PA. Is anorectal endosonography valuable in dyschesia? Gut. 2002;51:695-700.

30. Wald A, Caruana BJ, Freimanis MG, Bauman DH, Hinds JP. Contributions of evacuation proctography and anorectal manometry to evaluation of adults with constipation and defecatory difficulty. Dig Dis Sci. 1990;35:481-7.

Received 8/2/2010

Accepted 12/5/2010 